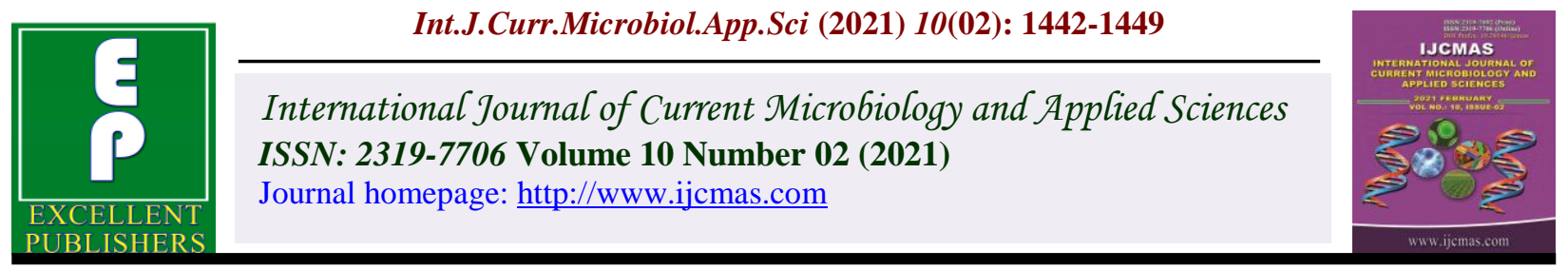

Original Research Article

https://doi.org/10.20546/ijcmas.2021.1002.173

\title{
Influence of Foliar Fertilization of Micronutrients on Leaf Micro Nutrient Status of Sweet Orange cv. Blood Red
}

\author{
Manoj Bhanukar, Preeti* and G. S. Rana \\ Department of Horticulture, CCS HAU, Hisar, Haryana, India \\ *Corresponding author
}

\section{A B S T R A C T}

Keywords

Sweet orange,

Foliar application, micronutrients

Article Info

Accepted:

10 January 2021

Available Online:

10 February 2021
An experiment was conducted during 2016-17 and 2017-18 to assess the performance of sweet orange $\mathrm{cv}$. Blood Red to foliar application of micronutrients. The study comprised of thirteen treatments viz., $\mathrm{ZnSO}_{4}$ $0.25 \%, \mathrm{ZnSO}_{4} 0.50 \%, \mathrm{ZnSO}_{4} 1.00 \%, \mathrm{FeSO}_{4} 1.5 \%, \mathrm{FeSO}_{4} 2.0 \%, \mathrm{FeSO}_{4}$ $2.5 \%, \mathrm{MnSO}_{4} 0.25 \%, \mathrm{MnSO}_{4} 0.50 \%, \mathrm{MnSO}_{4} 1.00 \%, \mathrm{H}_{3} \mathrm{BO}_{3} 0.1 \%, \mathrm{H}_{3} \mathrm{BO}_{3}$ $0.2 \%, \mathrm{H}_{3} \mathrm{BO}_{3} 0.3 \%$ and Control (No micronutrients). The plants were sprayed with micronutrients on first week of april and first week of july. The results showed that foliar application of micronutrient alone significantly increased the individual micronutrient content as compared to other and control. Therefore, application of micronutrients as foliar spray reduces incidence of deficiency calamities, in turn flourishes the growth and yield attributes subsequently.

\section{Introduction}

Citrus is the leading group of fruit crops in the world, mainly grown in Brazil, China, India, United States and Argentina. The genus Citrus includes more than 159 species belonging to order Sapindales, family Rutaceae, sub-family Aurantioideae, tribe Citrae and subtribeCitrinae (Swingle, 1943). Citrus is a commercially important fruit crop of India and grown across its length and breadth with a production of 13200 thousand MT from an area of 1034 thousand hectares during year of
2018-19 (Anonymous, 2019). Total sweet orange production in India is 3401 thousand MT with an area of 190 thousand hectares during year of 2018-19 (Anonymous, 2019). Sweet orange (Citrus sinensis (L.) Osbeck) has been reported to be originated in Southern China and it was introduced to India during thirteenth century (Swingle, 1943; Webber, 1948). It is the second largest citrus fruit, cultivated in tropical and subtropical regions of the country. In India, sweet orange is mainly cultivated in Andhra Pardesh, Maharashtra, Karnataka, Punjab, Rajasthan 
and Haryana. The survey conducted by Ahlawat et al., (1982) and Chauhan et al., (1984) revealed that the entire citrus belt of Haryana is deficient in various nutrients which needs immediate attention for its rectification. The micronutrients are needed in smaller amounts as compared to primary nutrients but these are equally important for plant metabolism (Katyal, 2004). In semi-arid states like Haryana, the physiological availability of these trace elements to plants absorption is hindered due to soil alkalinity, lower organic matter content and competition from other nutrients. Foliar application of micronutrients like $\mathrm{Zn}, \mathrm{Cu}, \mathrm{Mn}, \mathrm{B}$ and $\mathrm{Fe}$ has advantages over soil application because of high effectiveness, rapid plant response, convenience and elimination of toxicity symptoms brought about by excessive soil accumulation of such nutrients (Obreza et al., 2010). It was found (Swietlik, 2002) that mineral nutrient enters into leaf in three steps: (1) penetration through the cuticle and epidermal walls; (2) adsorption on the surface of the plasmalemma and (3) passage through the plasmalemma into cytoplasm.

Growth of citrus also influenced by micronutrient such as Zinc, Iron, Boron and Manganese. These elements affect metabolic functions in plant system. Zinc is an important micro element essential for plants due to its involvement in the synthesis of tryptophan which is a precursor of indole acetic acid synthesis (Ahmad et al., 2012).

Zinc has important role in starch metabolism and acts as co-factor for many enzymes, affects photosynthesis reaction, nucleic acid metabolism and protein biosynthesis (Alloway, 2008).

Iron is one of the most important micronutrient for plant growth. It is involved in various physiological processes of plant systems, namely chlorophyll formation and degradation synthesis of protein which contains chloroplasts and electron carriers in enzyme systems (Somasundaram et al., 2011). Boron plays significant role in growth, productivity of citrus and resistance to disease infection. It increases pollen grain germination, pollen tube elongation, consequently increasing fruit set percentage and seeds, fruit development and finally the yield (Abd-Allah, 2006). Manganese plays a vital role in plant physiological processes (viz., photosynthesis, respiration and nitrogen metabolism). Manganese primarily functions as part of the plant enzyme system, activating several metabolic functions (Somasundaram et al., 2011). Keeping in view the present investigation was planned to standardize the dosage of micronutrients to reduce the incidence of deficiency calamities of micronutrients.

\section{Materials and Methods}

The present investigation was carried out on fifteen years old sweet orange cv. Blood Red trees planted at a spacing of $6 \mathrm{~m} X 6 \mathrm{~m}$ in experimental orchard of Department of Horticulture, CCS HAU, Hisar situated at $215.2 \mathrm{~m}$ above mean sea level with coordinates of $29^{\circ} 10^{\prime} \mathrm{N}$ latitude and $75^{\circ} 46^{\prime}$ E longitudes, during the year 201617 and 2017-18. The experiment comprised of thirteen treatments.

Treatments were allocated in randomized block design (RBD) with three replications in each treatment. The study was comprised of thirteen treatments viz., $\mathrm{ZnSO}_{4} 0.25 \%, \mathrm{ZnSO}_{4} 0.50 \%, \mathrm{ZnSO}_{4} 1.00 \%$, $\mathrm{FeSO}_{4} 1.5 \%, \mathrm{FeSO}_{4} 2.0 \%, \mathrm{FeSO}_{4} 2.5 \%$, $\mathrm{MnSO}_{4} 0.25 \%, \mathrm{MnSO}_{4} 0.50 \%, \mathrm{MnSO}_{4} 1.00 \%$, $\mathrm{H}_{3} \mathrm{BO}_{3} 0.1 \%, \mathrm{H}_{3} \mathrm{BO}_{3} 0.2 \%, \mathrm{H}_{3} \mathrm{BO}_{3} 0.3 \%$ and Control (No micronutrients).

For foliar application, spray solutions were prepared by thoroughly dissolving in 
appropriate quantity of water. The treatments were given twice; first week of april and first week of july.

The recommended standard package of practises and plant protection measures were adopted to keep the plants in good health. The nutrient analysis of leaves for $\mathrm{Zn}, \mathrm{Fe}, \mathrm{Mn} \& \mathrm{~B}$ will be carried out at the following stages:

New flush : March

After fruit set : May

Fruit development : September

After harvesting : November

\section{Procedure}

For determining the leaf nutrients status,5-6 healthy leaf samples from nonfruiting shoots were collected and washed under running tap water followed by $0.1 \% \mathrm{HCl}$ and two washings through distilled water.

The washed leaf samples were surface dried and then oven dried at $70^{\circ} \mathrm{C}$ for 48 hours. The dried samples were ground and sieved through muslin cloth for further analysis as per procedure suggested by Chapman (1964).

\section{Digestion of plant material}

For the determination of micronutrients viz., $\mathrm{Zn}, \mathrm{Fe}, \mathrm{Mn}$ and $\mathrm{B}$, the $0.5 \mathrm{~g}$ of ground leaf sample was taken in $50 \mathrm{ml}$ separate conical flasks and these were digested on a hot plate by adding $15 \mathrm{ml}$ diacid mixture (HNO3 : $\mathrm{HClO} 4$ in 4:1 ratio) as per the procedure described by Piper (1942). The total volume of aliquot for microelements was made to $50 \mathrm{ml}$.

The content of nutrients in the leaf samples was determined by using the following methods:

\section{Total Zinc, Iron and Manganese}

The DTPA extractable $\mathrm{Zn}, \mathrm{Fe}$ and $\mathrm{Mn}$ were estimated by using the method of Lindsay and Norvell (1978). The digested leaf samples were analyzed for determining zinc concentration on atomic absorption spectrophotometer and their contents were expressed in ppm.

\section{Total Boron}

The Boron was estimated by Hot Water Soluble method given by Berger and Truog (1939). The digested leaf samples were analyzed by spectrophotometer using azomethine-II reagent and its contents were expressed in ppm.

\section{Results and Discussion}

The data depicted in Table 1 clearly illustrated that the different micronutrient concentrations affected zinc content of leaves significantly in May, September and November.

The results were found non-significant in March. In year 2016, maximum zinc content of leaves (18.20, 22.16 and 21.78) during May, September and November was observed with foliar application $\mathrm{ZnSO}_{4} 1.00 \%$ followed by $\mathrm{ZnSO}_{4} \quad 0.50 \%(16.42,19.66$ and 20.06) and minimum (10.19, 10.40 and 10.42) in control, respectively.

In year 2017, maximum zinc content of leaves (17.58, 20.39 and 21.75) during May, September and November was observed with foliar application $\mathrm{ZnSO}_{4} 1.00 \%$ followed by $\mathrm{ZnSO}_{4} \quad 0.50 \%$ (15.94, 18.79 and 19.88) and minimum (10.69, 10.78 and 10.72) in control, respectively.

It was reported by Sajida and Hafeez (2000) in kinnow mandarin that increase in the $\mathrm{Zn}$ content of leaves may be due to its maximum absorption from $\mathrm{Zn}$ source and less translocation to the 
outer parts of the plant. Similar trend was observed by Nanaya et al., (1985) in Coorg mandarin and Tariq et al., (2007) in sweet orange, increase in the zinc concentration of treated trees suggested the potential benefit of exogenous application of $\mathrm{Zn}$ in the form of zinc sulphate to these trees. It is clear from Table 2 data that different micronutrient concentrations affected iron content of leaves significantly in May, September and November.

The results were found non-significant in March. In year 2016-17, highest iron content of leaves (110.28, 114.46 and 115.03) during May, September and November was observed with foliar application of $\mathrm{FeSO}_{4} \quad 2.5 \%$ followed by $\mathrm{FeSO}_{4} 2.00 \%$ (108.42, 112.30 and 113.99) and lowest (101.55, 101.66 and 101.60) in control, respectively.

During the year 2017, highest iron content of leaves (110.10, 113.55 and 115.70) during May, September and November was observed with foliar application of $\mathrm{FeSO}_{4} \quad 2.5 \%$ followed by $\mathrm{FeSO}_{4} 2.00 \%$ (107.29, 111.07 and 113.11) and lowest (102.03, 102.44 and 102.52) in control. The similar findings in increasing of iron content due to application of $\mathrm{FeSO}_{4}$ nutrient to leaves was reported by Kaur et al., (2015) in Kinnow mandarin.

Data presented in Table 3 showed that different micronutrient concentrations affected manganese content of leaves significantly in May, September and November. The results were found non-significant in March. In year 2016, maximum manganese content of leaves (46.64, 51.15 and 52.55) during May, September and November was observed with $\mathrm{MnSO}_{4} 1.00 \%$ followed by $\mathrm{MnSO}_{4} \quad 0.50 \%$ $(44.89,48.21$ and 50.65) and minimum (40.26, 40.53 and 40.60) in control, respectively.

In year 2017, maximum manganese content of leaves (50.55, 54.52 and 55.78) during May, September and November was observed with $\mathrm{MnSO}_{4} \quad 1.00 \%$ followed by $\mathrm{MnSO}_{4} \quad 0.50 \%$ $(47.25,51.35$ and 53.14) and minimum (40.32, 40.59 and 40.68) in control.

Table.1 Effect of foliar application of micronutrients on zinc content ( $\mathrm{ppm}$ ) of leaves of sweet orange cv. Blood Red

\begin{tabular}{|c|c|c|c|c|c|c|c|c|}
\hline \multirow[t]{2}{*}{ Treatments } & March & May & September & November & March & May & September & November \\
\hline & \multicolumn{4}{|c|}{2016} & \multicolumn{4}{|c|}{2017} \\
\hline $\mathrm{ZnSO}_{4} \mathbf{0 . 2 5 \%}$ & 10.98 & 15.16 & 18.06 & 18.98 & 10.34 & 14.35 & 17.40 & 18.68 \\
\hline $\mathrm{ZnSO}_{4} \mathbf{0 . 5 0 \%}$ & 10.66 & 16.42 & 19.66 & 20.06 & 10.09 & 15.94 & 18.79 & 19.88 \\
\hline $\mathrm{ZnSO}_{4} 1.00 \%$ & 10.78 & 18.20 & 22.16 & 21.78 & 11.03 & 17.58 & 20.39 & 21.75 \\
\hline $\mathrm{FeSO}_{4} 1.5 \%$ & 10.78 & 10.84 & 10.98 & 11.19 & 10.91 & 11.09 & 11.25 & 11.11 \\
\hline $\mathrm{FeSO}_{4} 2.00 \%$ & 10.89 & 11.05 & 11.45 & 11.27 & 10.82 & 10.86 & 11.12 & 11.29 \\
\hline $\mathrm{FeSO}_{4} 2.5 \%$ & 10.65 & 10.44 & 10.64 & 11.34 & 10.73 & 10.79 & 11.04 & 11.01 \\
\hline $\mathrm{MnSO}_{4} \mathbf{0 . 2 5 \%}$ & 10.22 & 10.34 & 10.40 & 10.49 & 10.98 & 11.05 & 11.24 & 11.12 \\
\hline $\mathrm{MnSO}_{4} \mathbf{0 . 5 0 \%}$ & 10.11 & 10.29 & 10.81 & 11.14 & 10.22 & 10.85 & 11.37 & 11.32 \\
\hline $\mathrm{MnSO}_{4} 1.00 \%$ & 10.49 & 10.87 & 10.99 & 10.78 & 10.91 & 11.04 & 11.12 & 11.20 \\
\hline $\mathrm{H}_{3} \mathrm{BO}_{3} 0.1 \%$ & 10.59 & 10.71 & 10.94 & 10.71 & 10.71 & 11.19 & 10.97 & 10.92 \\
\hline $\mathrm{H}_{3} \mathrm{BO}_{3} 0.2 \%$ & 10.44 & 10.69 & 10.84 & 10.72 & 10.59 & 10.79 & 10.85 & 10.87 \\
\hline $\mathrm{H}_{3} \mathrm{BO}_{3} 0.3 \%$ & 10.57 & 10.65 & 10.73 & 10.73 & 10.52 & 10.73 & 10.81 & 10.78 \\
\hline Control & 10.09 & 10.19 & 10.40 & 10.42 & 10.64 & 10.69 & 10.78 & 10.72 \\
\hline C.D. at $5 \%$ & NS & 0.64 & 1.02 & 0.91 & NS & 1.04 & 0.91 & 0.81 \\
\hline
\end{tabular}


Table.2 Effect of foliar application of micronutrients on iron content (ppm) of leaves of sweet orange cv. Blood Red

\begin{tabular}{|c|c|c|c|c|c|c|c|c|}
\hline \multirow[t]{2}{*}{ Treatments } & March & May & September & November & March & May & September & November \\
\hline & 2016 & 2017 & & & & & & \\
\hline $\mathrm{ZnSO}_{4} \mathbf{0 . 2 5 \%}$ & 101.61 & 101.65 & 101.98 & 102.32 & 102.11 & 102.14 & 102.97 & 102.63 \\
\hline $\mathrm{ZnSO}_{4} \mathbf{0 . 5 0 \%}$ & 101.88 & 102.09 & 102.16 & 102.38 & 102.17 & 102.37 & 102.89 & 102.66 \\
\hline $\mathrm{ZnSO}_{4} \mathbf{1 . 0 0}^{2}$ & 101.61 & 101.77 & 101.93 & 102.18 & 102.51 & 102.55 & 102.62 & 102.88 \\
\hline $\mathrm{FeSO}_{4} 1.5 \%$ & 101.28 & 106.74 & 110.47 & 112.11 & 102.22 & 105.11 & 109.19 & 111.08 \\
\hline$\underset{\%}{\mathrm{FeSO}_{4}} 2.00$ & 102.69 & 108.42 & 112.30 & 113.99 & 102.89 & 107.29 & 111.07 & 113.11 \\
\hline $\mathrm{FeSO}_{4} 2.5 \%$ & 101.98 & 110.28 & 114.46 & 115.03 & 102.77 & 110.10 & 113.55 & 115.70 \\
\hline $\begin{array}{c}\mathrm{MnSO}_{4} \\
0.25 \%\end{array}$ & 101.95 & 101.96 & 102.41 & 102.74 & 102.58 & 102.63 & 103.08 & 103.23 \\
\hline $\begin{array}{c}\mathrm{MnSO}_{4} \\
0.50 \%\end{array}$ & 101.99 & 102.01 & 102.56 & 102.75 & 102.39 & 102.64 & 102.94 & 103.01 \\
\hline $\begin{array}{c}\mathrm{MnSO}_{4} \\
1.00 \%\end{array}$ & 101.96 & 102.00 & 102.64 & 102.68 & 103.01 & 103.12 & 103.93 & 103.96 \\
\hline $\mathrm{H}_{3} \mathrm{BO}_{3} 0.1 \%$ & 101.82 & 101.88 & 102.28 & 102.75 & 102.44 & 102.46 & 102.54 & 102.79 \\
\hline $\mathrm{H}_{3} \mathrm{BO}_{3} 0.2 \%$ & 101.91 & 101.98 & 102.20 & 102.66 & 102.21 & 102.39 & 102.57 & 102.68 \\
\hline $\mathrm{H}_{3} \mathrm{BO}_{3} 0.3 \%$ & 102.16 & 102.18 & 102.51 & 102.70 & 102.51 & 102.59 & 102.60 & 102.74 \\
\hline Control & 101.48 & 101.55 & 101.66 & 101.60 & 101.94 & 102.03 & 102.44 & 102.52 \\
\hline C.D. at $5 \%$ & NS & 1.02 & 1.04 & 0.87 & NS & 1.21 & 1.49 & 1.33 \\
\hline
\end{tabular}

Table.3 Effect of foliar application of micronutrients on manganese content (ppm) of leaves of sweet orange cv. Blood Red

\begin{tabular}{|c|c|c|c|c|c|c|c|c|}
\hline \multirow[t]{2}{*}{ Treatments } & March & May & September & November & March & May & September & November \\
\hline & \multicolumn{4}{|c|}{2016} & \multicolumn{4}{|c|}{2017} \\
\hline $\mathrm{ZnSO}_{4} \mathbf{0 . 2 5 \%}$ & 40.19 & 40.32 & 40.61 & 40.65 & 41.13 & 41.26 & 41.65 & 41.83 \\
\hline $\mathrm{ZnSO}_{4} \mathbf{0 . 5 0 \%}$ & 40.81 & 41.07 & 41.80 & 41.99 & 40.98 & 41.21 & 41.38 & 41.78 \\
\hline $\mathrm{ZnSO}_{4} 1.00 \%$ & 40.99 & 41.11 & 41.32 & 41.55 & 40.41 & 40.55 & 40.87 & 41.12 \\
\hline $\mathrm{FeSO}_{4} 1.5 \%$ & 40.67 & 40.75 & 41.03 & 41.21 & 41.02 & 41.08 & 41.38 & 41.69 \\
\hline $\mathrm{FeSO}_{4} 2.00 \%$ & 41.06 & 40.99 & 41.25 & 41.39 & 41.19 & 41.23 & 41.70 & 41.95 \\
\hline $\mathrm{FeSO}_{4} 2.5 \%$ & 41.04 & 41.22 & 41.51 & 41.84 & 41.11 & 41.48 & 41.62 & 41.81 \\
\hline $\mathrm{MnSO}_{4} \mathbf{0 . 2 5 \%}$ & 40.28 & 43.23 & 46.44 & 48.58 & 40.87 & 45.63 & 48.10 & 50.21 \\
\hline $\mathrm{MnSO}_{4} \mathbf{0 . 5 0 \%}$ & 40.19 & 44.89 & 48.21 & 50.65 & 40.78 & 47.25 & 51.35 & 53.14 \\
\hline $\mathrm{MnSO}_{4} 1.00 \%$ & 40.44 & 46.64 & 51.15 & 52.55 & 40.98 & 50.55 & 54.52 & 55.78 \\
\hline $\mathrm{H}_{3} \mathrm{BO}_{3} 0.1 \%$ & 40.62 & 40.74 & 40.97 & 41.33 & 40.55 & 40.79 & 40.85 & 41.33 \\
\hline $\mathrm{H}_{3} \mathrm{BO}_{3} 0.2 \%$ & 40.89 & 40.93 & 41.30 & 41.55 & 40.43 & 40.65 & 40.82 & 41.37 \\
\hline $\mathrm{H}_{3} \mathrm{BO}_{3} 0.3 \%$ & 41.11 & 41.34 & 41.61 & 41.88 & 41.28 & 41.38 & 41.87 & 42.09 \\
\hline Control & 40.11 & 40.26 & 40.53 & 40.60 & 40.11 & 40.32 & 40.59 & 40.68 \\
\hline C.D. at 5\% & NS & 1.30 & 1.11 & 1.02 & NS & 1.09 & 1.69 & 1.14 \\
\hline
\end{tabular}


Table.4 Effect of foliar application of micronutrients on boron content (ppm) of leaves of sweet orange cv. Blood Red

\begin{tabular}{|c|c|c|c|c|c|c|c|c|}
\hline \multirow[t]{2}{*}{ Treatments } & March & May & September & November & March & May & September & November \\
\hline & \multicolumn{4}{|c|}{2016} & \multicolumn{4}{|c|}{2017} \\
\hline $\mathrm{ZnSO}_{4} \mathbf{0 . 2 5 \%}$ & 24.11 & 24.24 & 24.56 & 24.87 & 23.01 & 23.18 & 23.34 & 23.67 \\
\hline $\mathrm{ZnSO}_{4} \mathbf{0 . 5 0 \%}$ & 24.04 & 24.27 & 24.61 & 24.79 & 23.98 & 24.11 & 24.15 & 24.33 \\
\hline $\mathrm{ZnSO}_{4} 1.00 \%$ & 24.01 & 24.33 & 24.59 & 24.80 & 24.02 & 24.15 & 24.22 & 24.35 \\
\hline $\mathrm{FeSO}_{4} 1.5 \%$ & 24.28 & 24.97 & 25.09 & 25.27 & 23.16 & 23.26 & 23.50 & 23.69 \\
\hline $\mathrm{FeSO}_{4} 2.00 \%$ & 24.10 & 24.41 & 24.72 & 25.10 & 23.08 & 23.22 & 23.45 & 23.61 \\
\hline $\mathrm{FeSO}_{4} 2.5 \%$ & 24.65 & 24.89 & 25.06 & 25.15 & 23.19 & 23.43 & 23.72 & 23.90 \\
\hline $\mathrm{MnSO}_{4} \mathbf{0 . 2 5 \%}$ & 24.82 & 25.12 & 25.25 & 25.39 & 23.11 & 23.78 & 24.06 & 24.14 \\
\hline $\mathrm{MnSO}_{4} \mathbf{0 . 5 0 \%}$ & 24.13 & 24.60 & 24.81 & 25.16 & 24.01 & 24.06 & 24.19 & 24.35 \\
\hline $\mathrm{MnSO}_{4} 1.00 \%$ & 23.98 & 24.09 & 24.18 & 24.50 & 24.09 & 24.12 & 24.32 & 24.67 \\
\hline $\mathrm{H}_{3} \mathrm{BO}_{3} 0.1 \%$ & 24.01 & 28.66 & 31.94 & 33.26 & 23.97 & 27.15 & 31.65 & 33.03 \\
\hline $\mathrm{H}_{3} \mathrm{BO}_{3} 0.2 \%$ & 23.93 & 30.58 & 34.93 & 36.24 & 23.79 & 29.44 & 33.27 & 35.88 \\
\hline $\mathrm{H}_{3} \mathrm{BO}_{3} 0.3 \%$ & 23.97 & 32.31 & 36.23 & 38.80 & 23.15 & 31.31 & 36.10 & 38.78 \\
\hline Control & 23.99 & 24.05 & 24.10 & 24.48 & 23.06 & 23.12 & 23.22 & 23.38 \\
\hline C.D. at 5\% & NS & 1.13 & 1.17 & 1.24 & NS & 1.67 & 1.12 & 1.63 \\
\hline
\end{tabular}

This increase in leaf Mn content may be due to better uptake of Mn ion. Similar trend was observed by (Labanwskas et al., 1969). Hafeez and Izhar (2006) in sweet orange observed that $\mathrm{Mn}$ combined with $\mathrm{Zn}, \mathrm{Fe}, \mathrm{Cu}$ and $\mathrm{B}$ foliar spray mixture was not as effective in increasing leaf Mn content as compared to Mn alone.

Data given in Table 4 revealed that different micronutrient concentrations affected boron content of leaves significantly in May, September and November.

The results were found non-significant in March. In year 2016, maximum boron content of leaves (32.31, 36.23 and 38.80) during May, September and November was observed with $\mathrm{H}_{3} \mathrm{BO}_{3} 0.3 \%$ followed by $\mathrm{H}_{3} \mathrm{BO}_{3} \quad 0.2 \%$ (30.58, 34.93 and 36.24) and minimum (24.05, 24.10 and 24.48) in control, respectively.

In year 2017, maximum boron content of leaves (31.31, 36.10 and 38.78) during May, September and November was observed with
$\mathrm{H}_{3} \mathrm{BO}_{3} 0.3 \%$ followed by $\mathrm{H}_{3} \mathrm{BO}_{3} 0.2 \%$ (29.44, 33.27 and 35.88) and minimum (23.12, 23.22 and 23.38) in control, respectively.

The increase in nutrient content in leaves after spray might be due to absorption of sprayed micronutrients. The present study is partially supported with findings of Nehete et al., (2011) in mango and Khan et al., (2012) in Kinnow mandarin.

\section{References}

Abd-Allah, A.S. 2006. Effect of spraying some macro and micro nutrients on fruit set, yield and fruit quality of Washington Navel orange trees. $J$. Appl. Sci. Res., 2: 1059-1063.

Ahlawat, V.P., Dahiya, S.S. and Yamdagini, R. 1982. Study on the mineral composition of healthy and declining citrus trees. Progressive Horticulture. 14: 126-128.

Ahmad, S.K., Waseem, U., Aman, U.M., Rashid, A., Basharat, A.S. and Ishtiaq, 
A.R. 2012. Exogenous application of boron and zinc influence leaf nutrient status, tree growth and fruit quality of Feutrell's Early (Citrus reticulata Blanco). Pakistan Journal of Agricultural Sciences, 49(2): 113-119.

Alloway, B.J. 2008. Zinc in soils and crop nutrition. Int. Zinc Association Brussel, Belgium.

Anonymous. 2018-19. $3^{\text {rd }}$ Advance Estimate. http://www.nhb.org.in

Berger, K.C. and Truog, E. 1939. Boron determination in soils and plants. Ind, Eng. Chem. Anal. Ed. 11: 540-545.

Chapman, H.D. 1964. Suggested foliar sampling and handling techniques for determining nutrient status of some field horticultural and plantation crops. Indian Journal of Horticulture, 21: 98118.

Chauhan, K.S., Ahlawat, V.P., Khera, A.P. and Dahiya, S.S. 1984. Nutritional survey of citrus orchards of Haryana. Haryana Journal of Horti. Sci., 13(34): 100-105.

Hafeez-ur- R and Izhar-ul- H. 2006. Diagnostic criteria of micronutrient for sweet orange. Soil Environ., 25(2): 119-127.

Katyal, J.C. 2004. Role of micronutrients in ensuring optimum use of macronutrients. In: Proceedings of International symposium on micronutrients, New Delhi, India. Pp. 3-17.

Kaur, N., Monga, P.K., Arora, P.k. and Kumar, K. 2015. Effect of micronutrient on leaf composition, fruit quality and yield of Kinnow mandarin. J. Appl. Nat. Sci., 7(2): 639643.

Khan, A.S., Ullah, W., Malik, A.U., Ahmad, R., Saleem, B.A. and Rajwana, I.R. 2012. Exogenous application of boron and zinc influence leaf nutrient status, tree growth and fruit quality of
Feutrell's Early (Citrus reticulata Blanco). Pakistan Journal of Agricultural Sciences, 49(2): 113-119.

Labanwskas, C.K., Jones, W.W. and Embrleton, T.W. 1963. Effect of foliar application of manganese, zinc and urea on yield and quality of Valancia orange and nutrient concentrations in the leaf, peel and juice. Proc. Amer. Soc. Hort. Sci., 82: 142-153.

Lindsay, W.L. and Norvell, W.A. 1978. Development of a DTPA soil test for zinc, iron, manganese and copper. Soil Sci. Soc. Am. J., 42: 421-428.

Nanaya, K.A., Anjaneylu, K. and Kotur, S.C. 1985. Effect of foliar applied Zn, Mn, $\mathrm{Cu}$ and $\mathrm{Mg}$ on growth parameters, chlorosis and interrelationships of micronutrients in leaf tissue of Coorg mandarin. Prog. Hort., 17: 309-314.

Nehete, D.S., Padhiar, B.V., Shah, N.I., Bhalerao, P.P., Kolambe, B.N. and Bhalerao, R.R. 2011. Influence of micronutrient spray on flowering, yield, quality and nutrient content in leaf of mango cv. Kesar. Asian Journal of Horticulture, 6(1): 63-67.

Obreza, T.A., Zekri, M., Hanlon, E.A., Morgan, K., Schumann, A. and Rouse, R. 2010. Soil and Leaf Tissue Testing for Commercial Citrus Production. Cooperative Extension Service, University of Florida, Cooperative Extension Service, Institute of Food and Agricultural Sciences, University of Florida, Florida. Pp. 24-32.

Piper, C.S. 1942. Soil and Plant Analysis. Hassell Press, Adelaide, Australia.

Sajida, P. and Hafeez-ur-R. 2000. Effect of foliar application of zinc, manganese and boron in combination with urea on the yield of sweet orange. Pak. J. Agri. Res. 16(2): 135-140.

Somasundaram, J., Meena, H.R., Singh, R.K., Prasad, S.N. and Parandiyal, A.K. 2011. Diagnosis of micronutrient 
imbalance in lime crop in semi-arid region of rajastan, India. Communications Soil Sci. Plant Analysis, 42: 858-869.

Swietlik, D. 2002. Zinc nutrition of fruit trees by foliar sprays. Acta Hort., Pp: 594.

Swingle WT. 1943. The botany of citrus and its wild relatives in the orange subfamily. In: Citrus Industry Webber H. S. Batchelor, D. L. (eds). University of California, Berkeley. 1: (128-4270).
Tariq, M., Sharif, M., Shah, Z. And Khan, R. 2007. Effect of foliar application of micronutrients on the yield and quality of sweet orange (Citrus sinensis L.). Pak. J. Biol. Sci., 10(11): 1823-1825.

Webber, HJ. 1948. Plant characteristic and climatology. Chapter II In Citrus Industry. Ed. By Batcelor, L. D. and Webber, H. J., Univ. Calif. Press Berkeley and Los Angeles. Vol. I.

\section{How to cite this article:}

Manoj Bhanukar, Preeti and Rana, G. S. 2021. Influence of Foliar Fertilization of Micronutrients on Leaf Micro Nutrient Status of Sweet Orange cv. Blood Red. Int.J.Curr.Microbiol.App.Sci. 10(02): 1442-1449. doi: https://doi.org/10.20546/ijcmas.2021.1002.173 